\title{
La Chambre Poétique
}

No, I won't leave the world - I'll enter a
lunatic asylum and see if the profundity of
insanity reveals to me the riddles of life.

(Kierkegaard: Journal 1836-1837)

\section{Shadow Plays}

What is a chambre poétique? First, an allusion to Roland Barthes' La chambre claire. Notes sur la photographie and its reference to the camera lucida. Let's follow this trace.

A camera lucida is an auxiliary instrument for drawing. Using a prism that is attached to a drawing board with a tripod, the artist can sight the object through an eyehole and also see a prismatic projection of the same object directly on the paper. But it is not a purely technical achievement that makes this divided view possible. The camera lucida is, in a figurative sense, a mediation between an external object of perception, the projected appearance on the paper, the mental imagination, and the somatic recording process. In the gaze, the external object translates itself into a pictorial reflection on the object whose appearance the artist's hand captures as an outline.

We remember the myth of the origin of painting: skiagraphy. Pliny reports that the daughter of the sculptor Butades, to capture the image of her beloved, framed his shadow in lines on a wall by the light of a lamp (Plinius Hist. Nat. XXXV 151). The shadow is a testimony of a person, paradoxically, both present and absent, a genuine expression of ephemerality. The draftswoman looks at a faint echo, the shadow, and translates it to another level of presence, the silhouette drawn on the wall. Within the contours, the picture is empty, merely a dark surface like a sheet of paper not yet written on.

For Barthes, the photographic projection of light guarantees a reference that is somehow present in the picture, yet without by any means losing its intangible nature. The object is there - without it there would be no projection - but it is equally absent. Each picture offers a momentary record that extracts something from the flow of time and captures it photo-graphically, i.e., as a light drawing. Photography brings something to light: it is an art of light and shadow, it creates a pictorial sphere of appearances. But what of a human being can be experienced through a picture? In his phenomenological observations on photography, Barthes starts from an experience of loss. It is a sadness (chagrin) that is evoked by the image, like a fleeting shad- 
ow from another world. The external picture can thus almost evoke a desire, a deep love, or cause pain. It tears open a wound in the self-reflection of the viewer. ${ }^{1}$

The relationship between interior and exterior views, their translation into a projective, poetic room of reflection, and the material representations shall guide us in the following to room situations. In the figurative as well as in the literal sense: to poetic chambers as places of a shadow theater and thus to a specific form of poetic imagery, self-reflection, and criticism.

But can images - those in language, painterly, photographic or performative communicate something of the inner life of a singular person?

\section{Poetic Shadow Casting}

It is Søren Kierkegaard who, using shadow silhouettes (Skyggerids), considers the possibility of depicting the interior. There are movements of the soul that take place on the surface: they are written on the face, as we say. For instance, moods such as joy or immediate sadness might be read off the facial features and included in a picture. ${ }^{2}$ Kierkegaard, however, is concerned with invisible, existential forces hidden deeply in the abyss of the soul, something which he calls 'reflective sorrow' (reflekterede Sorg). ${ }^{3}$ The I is aware of this inner sorrow but is unable to completely understand it and therefore constantly struggles with itself. These inner struggles do not manifest themselves to the outside world and remain under cover.

The 'reflective sorrow' is constantly in motion and does not understand the reason for its sadness, and thus wanders around searching. It refuses a direct depictability. ${ }^{4}$ This irreducible obscurity is one dimension of poetic critique. It is directed against physiognomic character studies that claim to analyze the interior of the soul.

Barthes has emphasized that the evidence of the photographic image, as far as human beings are concerned, is always accompanied by a genuine enigmaticalness, an ambiguous présence-absence (Maurice Blanchot). For even if the photographic image certifies the existence of a person, a "croyance fondamentale" (Barthes $1980,44,165)$, some inaccessibility remains nevertheless. And this is where the shadows come into play. What emerges in the representation is a mode of expression

1 "I wanted to explore it not as a question (a theme) but as a wound: I see, I feel, hence I notice, I observe, and I think." (Barthes 2006, 8, 30)

2 Kierkegaard knew the Physiognomic Fragments of Lavater, who illustrated his studies with silhouettes (see Liessmann 2017, 133).

3 The Danish term sorg has a wide range of meanings, including sorrow, grief, worrying about, caring for (omsorg), and thus loving attention. We can interpret sorg here as an existential restlessness in relation to another person or challenging circumstances of life.

4 "The exterior pallor [ydre Bleghed] is, as it were, the interior's good-bye, and thought and imagination [Tanken og Phantasien] hurry after the fugitive, which hides in the secret recesses." (Kierkegaard 1988, 169; Kierkegaard 1920, 170) 
(“air”), or, to put it more accurately, a unique aura5: "The air (air) is not a schematic, intellectual datum, the way a silhouette is. Nor is the air a simple analogy (analogie) [...]. No, the air is that exorbitant thing (cette chose exorbitante), which induces from body to soul - animula, little individual soul [...]. Thus the air is the luminous shadow (L'air est ainsi l'ombre lumineuse) which accompanies the body; and if the photograph fails to show this air, then the body moves without a shadow," i.e., if the photograph is not able to "supply the transparent soul its bright shadow (donner à l'âme transparente son ombre claire), the subject dies forever" (Barthes 2006, 45, 109-110; Barthes 1980, 45, 167-170).

Kierkegaard's reflective sorrow is a constant back and forth, like the restless up and down in the smallest of spaces. It is not written on the face but only hints at itself. It gives a wink (Vink) or lays a trace (Spor). Because of its restlessness it is a constant becoming (bestandig $i$ Vorden). There is no fixed state that could be labeled with a word and so the reflective sorrow is left to poetic or psychological treatment ("poetiske eller psychologiske Behandling” [Kierkegaard 1920, 173]).

We will follow Kierkegaard's poetic path, which may stand for the reflection on a blind spot of the self, confronting itself with shadows cast by itself. The dynamics of reflective sorrow make an artistic representation impossible. Nevertheless, it is poetic images that by means of spatialization and temporalization lay a trace.

Like a squirrel in its cage, it turns around in itself, yet not as uniformly as does that animal, but with a continual alternation in the combination of the interior elements of sorrow (i Combinationen af Sorgens indre Momenter). [...] Just as the patient in his pain tosses from one side to the other, so reflective sorrow is tossed about in order to find its object and its expression (Udtryk). (Kierkegaard 1988, 170; Kierkegaard 1920, 170)

It seems as if this ineffable sadness has closed up within itself and retreated against the outside world into an enclosure, the existence of which only a careful observer would even suspect. Kierkegaard creates poetic images that involve the reflection of the reader, who is quite familiar with such scenarios of the troubled self. The reflective sorrow almost rushes inwards, withdraws into the invisible.

By withdrawing inward in this way, it finally finds an inclosure (Indelukke), an innermost retreat, where it thinks it can remain, and now it begins its uniform movement. Like the pendulum in a clock, it swings back and forth and cannot find rest. It continually begins from the beginning and deliberates anew, interrogates the witnesses, checks and examines the various statements, something it has already done hundreds of times, but it never finished. In the course of time, the uniformity has something anesthetizing about it. Just as [...] the monotonous sound of a man pacing back and forth with measured steps on the floor above [...] and deep within, in its little nook, grief (Sorg) lives like a well-guarded prisoner in an underground prison

5 In French, air (wind, breath) refers also to a look, a facial expression of grace or charisma, and

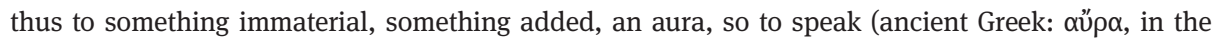
sense of a breath of air), the je ne sais quoi in relation to an unmistakable person. 
[...], walking to and fro in his cubbyhole (Aflukke), never weary of traveling the long or short road of sorrow. (Kierkegaard 1988, 170 -171; Kierkegaard 1920, 171)

This may sound like total seclusion, but this wandering in reflections (vandre frem og tilbage $i$ Reflexionen) is poetically expressed in pictures (Billeder). Kierkegaard calls them shadow cuts (Skyggerids).

On the one hand, these silhouettes are something that comes from the dark side of life; they are, as it were, shadows that lie on the soul, whose dark reasons cannot be expressed in language, like a trauma that appears in shadows in reflection (Kierkegaard 1920,172-173). On the other hand, these poetic shadow cuts are like outline drawings taken from the depths of the soul, in analogy to material silhouettes, like a scissor cut from black paper. But to bear witness to the subtle interior picture (det fine indere Billede) of the soul, the silhouette must first be brought to light. It must become visible in the medium of a projection. Here, the poetic mediation in spatial scenarios of inner movement becomes relevant (Kierkegaard 1920, 174).

If I pick up a silhouette, I have no impression of it, cannot arrive at an actual conception of it; only when I hold it up toward the wall and do not look at it directly but at what appears on the wall, only then do I see it. So it is also with the picture I want to show here, an interior picture that does not become perceptible until I see through the exterior. (Kierkegaard 1988, 173)

The soul's constant turmoil is transferred into the spatial movement of silhouettes that can be imagined cinematographically, like a shadow theater. We move into a performance. The light of reflection, i.e., the interaction between the poet or the poetic language and the reader stages the shadows and lets them act as if they were alive.

The way of looking and the mediation through light are decisive for the silhouettes in poetic words. Only when they are set in motion and held against the light so as to create a projection on the wall does something become perceptible or at least foreshadowed. This, however, only succeeds for those who have sympathy for the sorrow in its secrecy (Sympathien nemlig med Sorgens Hemmelighed), because it indeed lurks about the world in secret (Kierkegaard 1920, 174).

It is dialectical correlations of pictorial expression, external perceptions, and notions of the interior that Kierkegaard addresses, and here the manner of poetic representation and the interpretation of the reader play a constitutive role.

One walks down the street; one house looks like the other. Only the experienced observer suspects (prøvede Iagttager ahner) that in this particular house things are quite otherwise at the midnight hour; then an unhappy person paces about, one who found no rest; he goes up the stairs, and his footsteps echo in the stillness of the night. People pass one another in the street; one person looks just like the next, and the next one is like almost everyone else. Only the experienced observer suspects that deep within that one's head resides a lodger [Indsidder] who has nothing to do with the world but lives out his solitary life in quiet home-industry work. (Kierkegaard 1988, 174; Kierkegaard 1920, 175) 
The uniformity of the streets, buildings, people - as it were, a typeface of external life and its standardization in an era of urbanization, industrialization - the monotony of life's rhythms, the anonymity of the individual in the masses, the indifference towards one another, and the apparent silence of a night that seems to absorb everything individual, all this is only facade (lat. facies), i.e., the outwardly turned face of inner life. For the sympathizers of secrecy, only such messages of the hidden (e)motion deep down become perceptible. If we look at the world with the gaze of poetic sensibility, then what echoes outwardly, i.e., poetic picture-writing, is able to convey tuneful written or pictorial signals from a distance, like a 'tele-graphic message' ("telegraphisk Esterretning” [Kierkegaard 1920, 175]).

Poetry as telegraphy. These material telegraphies are always also ways of critically reflecting on that which sorrow has forced into its lonely cell.

Kierkegaard's chamber plays of the soul are not simply stagings of inwardness as a retreat from the world in locked rooms. Although Theodor W. Adorno criticizes Kierkegaard's interiors as expressions of an objectless inwardness, he also points out a negative aesthetic in Kierkegaard's poetic language (Adorno 1979, 57). As we will see, the chamber scenes are not simply a refuge in the face of a world of social alienation and massification, or an exclusion of real-world events under the illusion that one can withdraw into oneself unaffected by exterior influences. Indeed, the world is always inscribed in the intérieur.

We encounter here neither places of longing for intimacy, nor retreats of a bourgeoisie into the shells of privacy (Benjamin), nor enclaves of an inspired artistic existence. However, Kierkegaard plays with all these implications. But broken projective spaces are the result, stagings of tough processes of reflection, overshadowed by fleeting time and the dark voids of the soul. He goes to court with the illusionary stages of the private sphere.

Indirectly, the poetic reflections on the discord of the self are indicators of the conditions of the outside world as experienced. The poetic-philosophical treatment of all the inner staging takes up a literary topos (Becker 1990; Lange 2007; Schürmann 2015; Stiegler 2010) to poetically reformulate and criticize it, not least with a view to romantic approaches. By means of these translations, Kierkegaard performs poetic criticism in the sense of Schlegel, because "poetry can only be criticized through poetry. An art judgment which is not itself a work of art, either in the material, as a representation of the necessary impression in its becoming, or through a beautiful form, and a liberal tone in the spirit of the old Roman satire, has no civil right at all in the realm of art" (Schlegel 1967 [1797], 162 [fr. 117]). ${ }^{6}$

Let us try to see how the poetic chambers create, as it were, light-writings of both a reference to the self and the world, and recall Kierkegaard's fine indere Billede, which casts vivid shadows only in poetic representation - not in fixed silhouettes,

6 Throughout the text, all translations of Schlegel's texts are my own. 
but by making an appearance in its movement and giving us a glimpse of the inner life of the soul. What is needed is a light that brings the shadow to life by throwing them against the wall. This happens in the medium of poetry.

\section{Emigration of imagination, so that the legs can never come along ${ }^{7}$}

Kierkegaard subjects Schlegel's concept of a romantic universal poetry and the aesthetic way of life to rigid criticism. He shares the romantic impetus against the narrow-mindedness and conventions of a philistine bourgeoisie. ${ }^{8}$ But he confronts with existential questions the romantic liberation of the poetic spirit and the idealization of an independent practice of freedom. Romantic poetry appears to him as an escape from the world, an "emigration from reality," and as the illusion of poetic art ascending to a realm of fantastic infinity, thereby losing sight of the ground of reality under the feet of finite life.

Kierkegaard counters such forgetfulness of the self and the world, including a lack of historical awareness, with an ethical paradox. The individual is confronted with existential challenges, struggling with contradictions and the intricacies of freedom, which always bear the risk of failure. This does not mean that the aesthetic approach is obsolete, but it should not simply be a flight of fancy. It has to be transposed into the realm of ethics, i.e., poetical language has to be reconnected with 'real life' in order to fight the constant battle between finitude and infinite possibilities, temporality and eternity. Attempts to suspend these existential tensions by making reference to idealized worlds or the support of philosophical systems ${ }^{10}$ appear as deceptions, which do not hold true from the perspective of the "doghouse."11

The leap of faith promises the only moment of hope for the desperate. For Kierkegaard, we cannot survive the paradox of our fragile, worldly existence without believing in an event of grace, that is, an a priori certainty of God and of reconciliation.

7 Kierkegaard 1905, 177.

8 Kierkegaard has no primary socio-critical concern. But the invectives against the conventions of the bourgeoisie, the strategies of escape through business and routines, and finally the doctrinaire paralysis of Christianity - all this forms the background of his thematization of the individual that exists in the tension between the finite and the infinite, being confronted with decisions that cannot be met with literary escapades. Implicitly, this is always a critique of socio-historical realities.

9 See Schreiber 2014, 402.

10 This is also directed against Hegel's idea of a "self-reconciliation of the spirit” (Glöckner 1998, 143-144).

11 "A thinker erects a huge building, a system, a system embracing the whole of existence, world history, etc. and if his personal life is considered, to our amazement the appalling and ludicrous discovery is made that he himself does not personally live in this huge, domed palace but in a shed alongside it, or in a doghouse, or at best in the janitor's quarters.” (Kierkegaard 2013, 43-44) 
Let us consider the leap, beyond theological reassurance: Freedom requires decision-making and has to constantly deal with strong affections, impulses of the will, and agonizing existential doubts. It dwells with all the hesitation and indecision, furnishes itself with the fear of taking guilt upon itself. Can such a dare of life hope for a changeability of the world? What can take the place of reconciliation under the auspices of loss or doubt of transcendental shelter in the 20th century?

Here, what needs to be introduced is Kierkegaard's poetic telegraphy, which aims to return to life such indissoluble questions, placing them as actors in a poetic echo chamber.

\section{Hiking on the Wallpaper - actiones in distans}

In Kierkegaard's diaries, we are taught that the poetic imagination can try to escape from the soul's wearying home. But the effort to leave the gloomy state behind can lead to a loss of self-relationship. The self is not at home with itself; it is almost on the run.

Between my melancholy and my intimate 'Thou' there lay a whole world of fantasy. The world it is that I have partly exhausted in my pseudonyms. Just like a person who hasn't a happy home spends as much time away from it as possible and would prefer to be rid of it, so my melancholy has kept me away from my own self while I, making discoveries and poetical experiences, traveled through a world of fantasy. [...] [T] hat is how I behaved in melancholy towards possibility. (Kierkegaard 1938, JP, No. 641)

But when poetic imagination tempts us to free the self from grueling emotions and to embark on fantastic journeys, this can cause a feeling of terrible worldlessness.

Yet, while speaking in many tongues, this very self simultaneously discovers and experiences itself poetically. This points us to another dimension of poetry. It is the indirect poetic telegraphs, i.e., the speaking in pseudonyms or divided roles and episodes - elements of Romantic poetry - that become the medium of a poetic critique in voiced shadows.

The poetic polyphony evokes pictorial scenarios which, like a shadow theater, give an inkling of the fine inner image of the soul and the unspeakable sorrow. Like an aesthetic game of hide-and-seek, it brings the reader out of his shell, confronting him with modes of self-deception. Poetry stages self-questioning that does not provide an agenda, but engages a sympathetic reader who knows about the shallows of the soul. The ethical challenge of existence appears on a poetic stage or in a rehearsal room of decision (see Feger 2007, 543).

Prototypically, this is played out in Repetition, and, here too, the crystallization of poetic criticism is reflected in a room scene. 


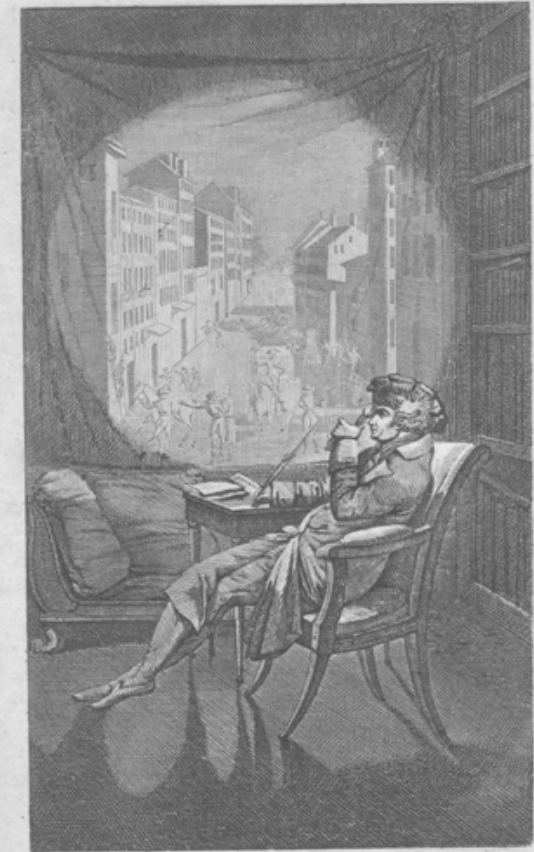

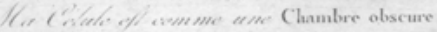

\section{L'HERMITE}

D E

LA CHAUSSÉE-D'ANTIN,

o v

OBSERVATIONS

SUR LES MEURS ET LES USAGES PARISIENS

AU COMMENCEMENT DU XIXe SIÈcLE.

QUATHIÈME ÉDHTHOX.

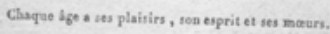

Both, Art Poelh

TOME PREMIER.

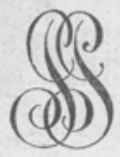

A PARIS,

CHEZ PILLET, IMPRIMEUR-LIBRAIRE, RUE CHRISTINE, $\mathrm{N}^{\circ} 5$. 1814 .

Fig. 1: Etienne de Jouy: L'Hermite de la Chaussée-d'Antin, ou Observations sur les mœurs et les usages parisiens au commencement du XIXe siècle. Paris 1814.

The book's frontispiece shows the scholar in a library, his hand holding the pen on the side table rather casually set up for writing, seated reclined in the armchair, completely concentrated on intently gazing through a lorgnette, which here projects the light of the imagination like a lens onto a curtain that covers the window of the darkroom. The inner event of the imagination is shown in a circle of light, which makes a busy street scene visible. Just as if one could look out through the window, the interior extends perspectively into the imagined exterior space. It is like a cinema situation. Yet, this is not a matter of a fantasy world but of contemplating reality as it is experienced: "My chamber is like a camera obscura, in which the external objects can retrace their traces" (Ma cellule est comme une chambre obscure où viennent se retracer les objets extérieurs). A paradox draws attention to the way in which inner imagination and perception staged externally are here intertwined: The light of the imagination, which is laid on the curtain like a circular opening, is projected back into the scholar's room, where it creates shadows. Walter Benjamin refers to this title engraving in his Arcades Project [Passagen-Werk] (see Haug 2017, 42-43).

Let us imagine a traveler returning to a city and staying exactly in the same boarding house and the same room, just as he did on a previous trip. An attempt to repeat a happily remembered experience. Let us say it is Berlin on the Day of Prayer and Repentance and the whole city seems to lie under a thick layer of dust, seeming to bear 
witness to ashes to ashes, dust to dust, being thus overshadowed by a grey veil of transience. And now to the room:

When a fellow has settled himself cosily and comfortably in his quarters, when he has a fixed point (fast Punkt) like this from which he can rush out, a safe hiding place to which he can retreat and devour his booty in solitude (for i Eensomhed at fortrære sit Bytte) - something I especially appreciate, since, like certain beasts of prey, I cannot eat when anyone is looking on - then he familiarizes himself with whatever notable sights there may be in the city. (Kierkegaard 1983, 153)

A carnivore cave of poetic reflection. A starting point to capture booty in the world, to hide and disembowel it. The room may now be the point of departure for taking walks through the city or at least for hearing about it, or a fixed point for embarking on imaginary journeys and for only imagining possible experiences. Either way, the self runs away from itself.

In any case, these are scenarios in which the explored possibilities turn out to be a phantasm. They do not become active decisions but remain mere eventualities. The booty will always be captured from reality, depending on the interest or attention with which someone wanders through the streets, hurries, promenades, or strides purposefully. It is the poetic imagination that brings the booty to life. Let us imagine the poetic room like a theater stage of the imagining self, a shadow theater.

It is like in a real theater performance where especially a young person will be enraptured by the magic of the "artificial actuality in order like a double to see and hear himself and to split himself up into every possible variation of himself, and nevertheless in such a way that every variation is still himself" (Kierkegaard 1983, 154). A dissociation and multiplication of the self: While the body rests, the imagination experiences a multitude of facets of the self, which are not only visible but become audible as voiced shadows and sounds (lydende Skygge). These may now be mere fantasies, as they come over a young person who, on the threshold of awakening, is dreaming about his personality. Kierkegaard designs a shadow theater in which the ego meets poetic refractions of itself.

In such a self-vision of the imagination, the individual is not an actual shape but a shadow, or, more correctly, the actual shape is invisibly present and therefore is not satisfied to cast one shadow, but the individual has a variety of shadows (men Individet har en Mangfoldighed af Skygger), all of which resemble him and which momentarily have equal status as being himself. (Kierkegaard 1983, 154)

Kierkegaard uses romantic motifs - we may think of the doppelganger in E.T.A. Hoffmann or the shadow of Peter Schlemihl, of night scenes and dream visions. But he focuses on a pre-reflexive, dreamlike consciousness of the self, which stages its possibilities. The consciousness is not yet awake, it wanders between its possibilities. But these possibilities must be given shape and voice so that the dreaming I can become aware of them. "Each of its possibilities is an audible shadow (Enhver dets $\mathrm{Mu}$ lighed er derfor en lydende Skygge)" (Kierkegaard 1983, 155). The dreaming soul is still 
hovering over the abyss, not wanting to disentangle the crush of inner voices of fear, lament, anxiety, exuberance, not wanting to decide. And before one knows it, the individual has woken up from this dream state again and the voices of the night fall silent (Nattestemmerne forstumme).

If the voices do not fade, then there is another strategy, to flee from the challenge of freedom and to dance in sheer possibilities. "The stage is that kind of setting, and therefore it is particularly suitable for the Schattenspiel [shadow play] of the hidden individual (En saadan Omgivelse er den sceniske, som derfor netop egner sig for det krypte Individs Schattenspiel)" (Kierkegaard 1983, 156).

Now shadows move onto the stage, acting in different roles, in whose voices the individual rediscovers its own voice, as in a mirror image ("spellbinding") or echo chamber, and perhaps the individual puts itself in the role of a robber captain and goes through wild adventures (156). We are still in the chamber, but the imagination is drawing wider circles, has expanded into a theater space. It is a poetic means of demonstrating the existential questioning of the self and bringing it back into the world from the sleep of reason, which sometimes gives birth to monsters.

What is audibly and visibly staged in dreamlike imaginations of the youthful, childlike consciousness is the foil of a reflection into which the mature consciousness can dive, though not in weightless reverie, but when the soul at a mature age gathers itself in earnest, i.e., concentrates (157). A poetic undergoing of ethical challenges. To experience this, the reflective soul must look at things as if it were a child. $^{12}$

Therefore, the "more mature individuality who satiates himself on the strong food of actuality (Virkelighedens stærke Føde)" (158) does not turn to high art, such as painting, in particular, but to everyday art, the picture sheet, proceeding like a child who, in cutting out something concrete, revitalizes with this piece of paper a general existential question with a dizzying intensity. Again, it is about images that set the imagination free, silhouettes or cut-out pictures that come to life instantly and reflect something general in very concrete detail - and in this concreteness reach a depth of questioning that rejects all conventions, something which only the unbiased, and at the same time deeply serious, gaze can do.

In the days of childhood, we had such enormous categories that they now almost make us dizzy, we clipped out of a piece of paper a man and a woman who were man and woman in general in a more rigorous sense than Adam and Eve were. (Kierkegaard 1983, 158)

12 Kierkegaard here also alludes to a romantic motif of childhood, i.e. a sometimes mythologically idealized interpretation of childhood as a pre-rational and supra-rational stage that is characterized by the soul's inclination to dream and miraculous or almost prophetic insights into the future (for instance in Wackenroder or Novalis). But Kierkegaard does not romanticize a retrojected childlike felicity in terms of a mythological golden age. Rather, he focuses on the pre-conscious abilities of the child's playful soul, which resurfaces in the psyche of the adult, i.e. a foreboding memory of past suffering or an intuition or sentiment of pain and loss that foreshadow a future. 
The cut-out picture's reduction of objects to a very simple, popular form (as in the picture sheets of the eighteenth and nineteenth centuries) raises fundamental questions arising from the outlines of these pictures that call up memories or collective worldviews and carry them into the present. It is the gaze of the child that, beyond conventions, uncovers this deep questioning. ${ }^{13}$ Perhaps the words from Kierkegaard's Diapsalmata now become more lucid.

My sorrow is my baronial castle, which lies like an eagle's nest high up on the mountain peak among the clouds. No one can take it by storm. From it I swoop down into actuality and snatch my prey, but I do not stay down there. I bring my booty home, and this booty is a picture I weave into the tapestries at my castle. Then I live as one already dead. Everything I have experienced I immerse in a baptism of oblivion unto an eternity of recollection. Everything temporal and fortuitous is forgotten and blotted out. Then I sit like an old gray-haired man, pensive, and explain the pictures in a soft voice, almost whispering, and beside me sits a child, listening, although he remembers everything before I tell it. (Kierkegaard 1988, 42)

This can be read as a poetic procedure that transposes experiences of reality into images that cover the space of consciousness like wallpaper, a sheet of pictures that clad the walls. Whereas early (oriental) wallpapers were woven carpets, and then hand-painted or printed paper coverings of the walls, industrialization (around 1830) introduced a process of printing wallpapers with serial patterns on paper webs. But despite industrial production, connecting points and a certain unevenness in the print always remain visible. The wallpaper is, as it were, a montage. It covers the chamber with paper webs on which ornamental segments join together to form recurring patterns of pictorial writing. These are often stylizations of the floral world, such as abstractions of tendrils and plants. But it is precisely this translation into repetitive patterns that opens up a specific variability of forms for the imagination, that comes alive for the poetic spirit. The eye may follow the seams, can look for breaks and fractures; it knows each particular irregularity and, like a child, brings the patterns to life, sets them in motion, and thereby allows them to grow.

In Berliner Kindheit, Walter Benjamin describes how the bed rest prescribed by the doctor leads the fevered child to move from the bed to the interior: "Just as a man in a frenzy sometimes calculates and thinks, just to see: he can still do it, I counted the circles of sunlight that swayed on the ceiling of my room, and I arranged the lozenges of the wallpaper into ever new bundles.” (Benjamin 1972, GS IV, 272)

13 With reference to the childlike power of imagination in dealing with sheets of pictures, i.e., popular single-sheet prints whose pictorial motifs have been collected, cut out and pasted in, Walter Benjamin highlights the way in which traces of a cultural-historical worldview manifest themselves in simple outlines and break into the present. See Benjamin 1972, GS IV, 280-282 ("Das Pult") and 115 ("Unordentliches Kind"). In "Ich packe meine Bibliothek aus" (GS IV, 389-390), he emphasizes that the childlike nature of collecting is constitutive for the aged collector, too. Children are able to achieve a renewal of the given: they paint objects, cut them out, take them off, develop a scale of revivifications. 
For Kierkegaard, it is about questions of memory and renewal, about breaking out of the regimes of visibility and breaking up experience, which is translated into poetic imaginations. The child and the old man can do this, but all of this is not an internalization that is alien to the world. On the contrary, it starts with the experience of the world, extracts something from the empirical, i.e., focuses on details, reformulates these extracts into literary imagery, and the images learn to walk and pose questions for reflection.

And does this not require a distanced perspective or literary procedures that Kierkegaard calls actiones in distans? ${ }^{14}$ In these literary forms abstracted (subtracted) from the realm of life, the reader is confronted with challenges that life abandons. The poetic shadow play puts these questions at a reflective distance.

In "Das Fieber," Walter Benjamin tells of the childlike tendency to see everything as if it were coming towards him from far away (Benjamin 1972, GS IV, 269). Silhouettes are projected onto the wall. They only appear lively from a distance. They come towards the self or, like a reflection or vocal echo, come back to it. An actio in distans that opens a space for reflection. Thus, it is the child who, in the evening, by the light of a lamp, with the play of its fingers, projects shadow figures on the walls and brings stories to life.

I used my tranquility and the proximity of the wall I had in my bed to welcome the light with shadowy images. Now all those games that I had let my fingers play came back on the wallpaper. "Instead of being afraid of the shadows of the evening", as says my playbook, "funny children rather use it to have fun." (Benjamin 1972, GS IV, 272)

The bodily gestures and finger plays create a shadow theater, a distanced observation of one's own body and mental movements, which now run across the wallpaper as shadow figures and become the object of observation in the poetic room. ${ }^{15}$

What interests us here is not the childlike play that projects figures onto the walls, but in a figurative sense, the literary process that Kierkegaard develops with the shadow plays.

We are investigating procedures of a poetic actio in distans, which does not represent empirical reality, but rather brings it to life telegraphically, i.e., in projective narrative forms, figures, and gestures, and allows them to act as shadows in a poetic space, so that the producer, as well as the readers, become spectators and interpreters of the poetic staging.

Did not Schlegel emphasize this invigorating power of poetic criticism?

14 Kierkegaard 1988, 311. The actio in distans adapts as a literary method a scientific theory of the remote effect of forces (e.g., magnetism, gravity), according to which bodies can trigger an effect, change movement etc. without touching each other (see Tajafuerce 2000 and Blumenberg 2007). 15 Benjamin refers to 'Spielbücher' of the nineteenth century, here Leske 1914. See Brüggemann 2007, 49-67. 


\section{Gandidhatten.}

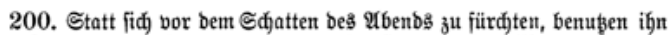

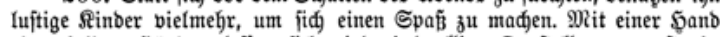

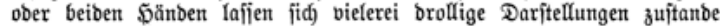
bringen: ફ̧äşden, Sđdräne, Brenabiere, Ejel, Biegen, Ddjien, Samele ufw. töntut an ber $\mathfrak{B a n b}$ crideinen, wenn man beide Sänbe in

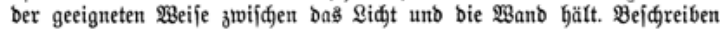

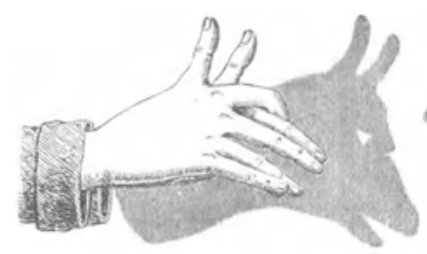

Fitg. 236.

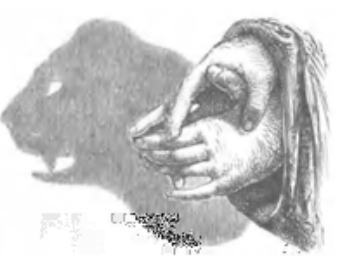

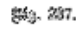

Fig. 2: Illustriertes Spielbuch für Mädchen. Ed. Marie Leske (1914), 99 (detail).

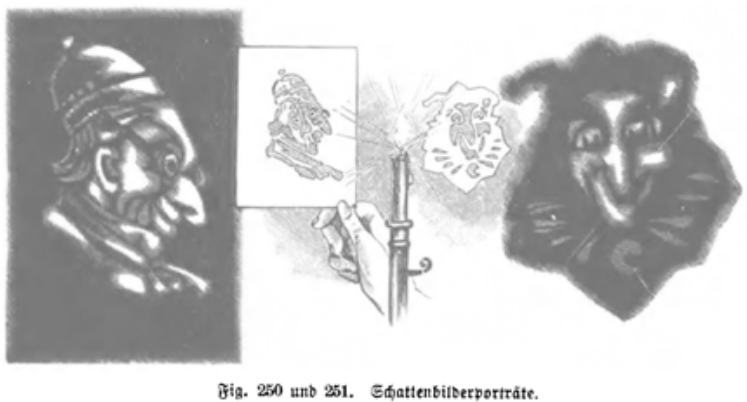

Fig. 3: Illustriertes Spielbuch für Mädchen. Ed. Marie Leske (1914), 102 (detail).

\section{On the wings of poetic reflection hovering in the middle}

For Friedrich Schlegel, poetic representation articulates not only an aesthetic reference to the world and the self but also a critical reflection on the prerequisites of poetic articulation. The role of the poet and his mode of representation, and, ultimately, the role of the sympathetic reader, are intertwined in a material, artistic language: "every [art and science] that does not find its essence in the words of language has an invisible spirit, and that is poetry" (Schlegel 1967 [1800], 304). ${ }^{16}$

The movement of the poetic spirit, according to this programmatic claim, bears witness to an artistic individual, manifests itself as a mirror of the world, or rather, of the age and its respective spirit, and continually relates itself to the surroundings.

16 Concerning language as the prototype of all artistic media, see Chaouli 2004, 138. 
Nevertheless, poetry "can hover most between the portrayed and the depicting, free of all real and ideal interest, on the wings of poetic reflection in the middle, potentiating this reflection again and again and multiplying it as in an endless series of mirrors." Here too, poetry is conceived as an optical projection of repetition and variation in multiplication. It is a process that takes place in an interplay not only "from within, but also from without,” as a continuous becoming (Schlegel 1967 [1798a], 182 [fr. 116]).

We may recall Kierkegaard's figure of the ceaseless movement of the weary self. The romantic ideal of mediation of all disciplines and the concept of mediating art and life are reversed in a radically existentialist turn of this hovering, which is hence subsequently modeled on the poetic room. It functions as a projection space of iterative reflections and moving image scenes, poetically interweaving inner and outer worlds and thus simultaneously addressing the status of poetry. But while Schlegel is concerned with "indulg[ing] oneself completely to the impression of a poem, letting the artist do with us what he wants," and, above all, with "be[ing] able to abstract from all the individual, to grasp the general in a suspended state," with Kierkegaard it becomes a task not to rely on this high "sense of the universe" or "to be able to rise above our own love and to destroy what we worship in our thoughts" (Schlegel 1967 [1798b], 130 -131). Rather, this romantic soaring is to be poetically criticized and reflected in terms of the concrete dizziness of the self in individual everyday life.

Kierkegaard takes up approaches of poetic criticism and turns them against what he considers to be a world-forgotten understanding of poetry. According to Schlegel, poetry as an art can only be critically assessed by poetry itself. Its realm is thus a cosmopolitan one, where citizenship is attained by sympoets and symphilosophers. ${ }^{17}$ Poetic critique crucially involves the role of reading or readership, i.e., the participation of a lively and resistant counterpart. It unfolds in a dynamic of interaction and inventions that set in motion a process of becoming. As poetic poetics (Schlegel 1967 [1798a], 170 [fr. 28]), it is a critique that is presented in a poetic way. Why? Because "every excellent work, of whatever kind, knows more than it says, and wants more than it knows” (Schlegel 1967 [1798b], 140), thus holding potentials that are unspoken and yet effective as implicit knowledge. In addition, there are those that cannot be gathered by the poet himself and yet are driven by a subliminal will. This requires an engagement with poetic texts that give ample reason for assumptions, interpretations, readings, and ways of understanding. But poetic criticism does not produce meanings in order to state, like "a mere inscription, only what the thing actually is, where it stands and should stand in the world” (Schlegel 1967 [1798b], 140). The poet and artist is at the same time a poetic and critical reader, i.e., 'translator,'

17 The synthetic writer creates a counteractive (entgegenwirkend) reader (see Schlegel 1967 [1797], 161 [fr. 112]). 
philosopher, rhetorician, and philologist. These readings and translations give new life to historical forms of representation and expressions.

Kierkegaard takes up procedures of romantic, poetic criticism, but it is the individual that is to be brought into focus, without abandoning the existing reality. It is necessary to win over the readers as sympathizers or symphilosophers and sympoets to lead them to the intimate stages of the self by means of indirect aesthetic transmission. These are stagings in which the struggle with reality is poetically articulated.

The reader must have sympathy for sorrow in its secrecy. Then a shadow theater staging the broken self within its worldly circumstances is created. It theatrically reflects existence in a world that cannot be reconciled poetically. But in these refractions - whether in terms of the illusory character of the promises of happiness, or of the stagings of tristesse, desire, or doubt, i.e., in negative aesthetics - a longing is expressed. It refuses any conciliatory tone and thus points dialectically to the unredeemed. ${ }^{18}$

Let us take up this poetology of self-mirroring and critical growth, as well as the demand for a revitalizing language. We enter a reflective, poetological cabinet of mirrors with a wealth of material refractions and turn to interior scenes in various media of poetic image formation to exemplify how they become the site, or Schauplatz (Benjamin), of poetic criticism.

\section{"Poems are painted window panes" (J.W. v. Goethe)}

We are looking at two paintings by Vilhelm Hammershøi (1864-1916), among a large number of interior paintings by the Danish artist. They provide insights into his private rooms in Copenhagen. The chamber scenes are held in color nuances of grey and white, which vary in soft bluish, ochre, and greenish color values. Particular furnishings or objects are given a haptic emphasis in the colors of their material (wood, glass, porcelain). The objects frequently appear entangled in an interplay between light and shadow as well as mirror reflections. The frugality of the indoor situations evokes the atmosphere of an extended period of temporal persistence as well as of a peculiar abandonment. However, the paralysis disappears when the viewer continues to contemplate the paintings. A subtle play of movements becomes evident, reacting to the outside, in momentary shots of the incoming light, which, despite the apparent standstill, points to the passing of time. The interiors manifest themselves as very sparsely furnished, almost empty, but not uninhabited. Often they are deserted like Hammershøi's landscape and cityscape paintings, which are mostly without people.

18 See Feger 2007, 543. On the dialectics of the fainting longing, see Adorno 1970, 199. 


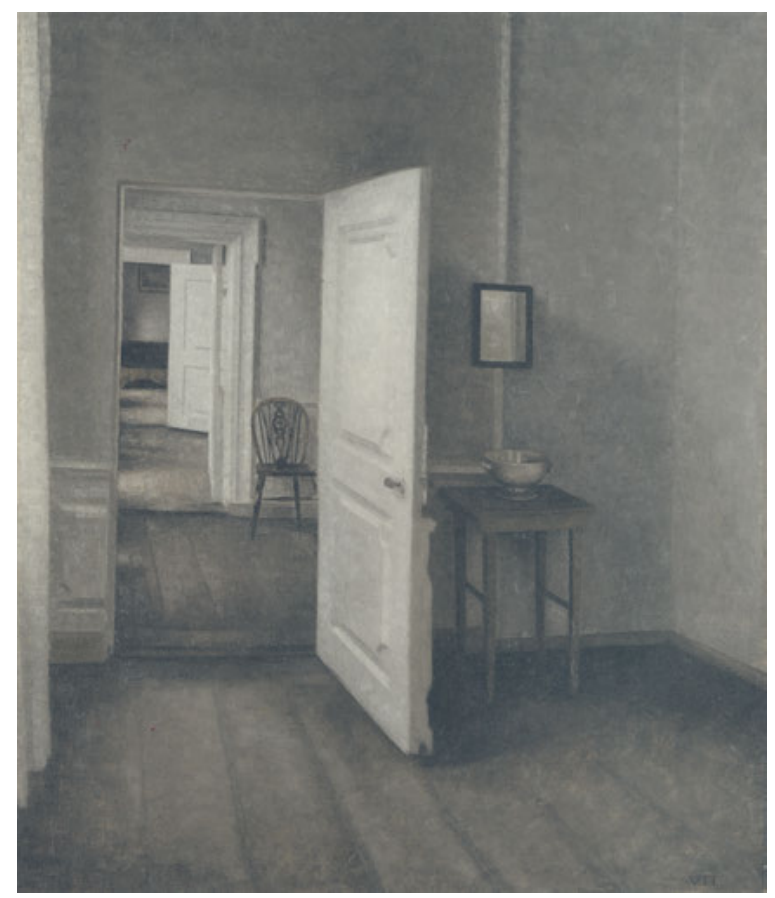

Fig. 4: Vilhelm Hammershøi, Interior. "The Four Rooms”, 1914 (Oil on canvas,33 1/2 × 27 4/5 inch; $85 \times 70.5 \mathrm{~cm})$, Ordrupgaard, Kopenhagen

Repeatedly, a female figure can be seen in the interiors, for which the painter's wife often acted as a model, always in a black floor-length dress, her hair tied in a knot, almost like a black silhouette. If we want to speak here of silence, then in the sense of taciturnity, which seems to exclude the hectic noise of the world. In the sparse rooms, traces of everyday life appear with the greatest sobriety.

The outside world appears as sunlight that causes a reverberation of shadows, light projections, and reflections. On many paintings, windows - some of which are shown open, others closed and subdivided - draw attention to the exterior of the interior. Light breaks in through the window crosses or the multiply framed panes; panels of light and crosses of shadow thus fall into the room. But the windows do not afford the gaze a plain view or any clear sight of the vastness of the sky, which is at best seen rather vaguely. If we are able to see what is happening outside the windows at all, this requires, for example, that we look at the window fronts of the opposite facades. Here, no (romantic) view into the open is granted. Rather, framed interior and exterior views intersect as a palimpsest of window crosses or framings in the gaze (fig. 5).

An inner courtyard view: The depiction of windows and framings always carries an allusion to painting or framed pictures, which exhibit themselves (Hemkendreis 2016). Beyond that, windows suggest a threshold or opening between inside and out- 


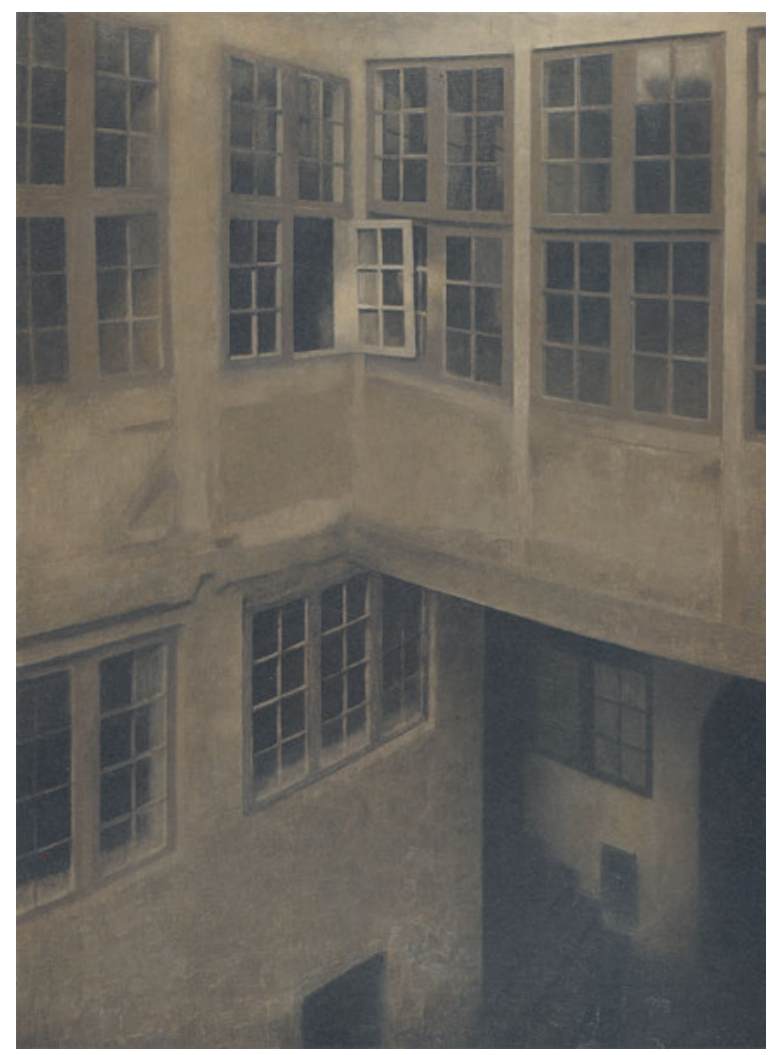

Fig. 5: Vilhelm Hammershøi, Courtyard. Strandgade 30, 1899 (Oil on canvas, 65,7 × 47,03 cm), Toldeo Museum of Art. Ohio

side. The series of windows running across a corner here points to something behind it, but the windows do not allow a deeper insight; they indicate shaded rooms or corridors, absorbed in darkness, but there are also light projections that fall into the interior.

Some of the windowpanes remain opaque and reject the spectator's view. Then again, they become mirror surfaces on which architectural elements and a piece of the sky are reflected. A ray of sunlight falls into this courtyard area and hits an open window wing on the first floor. The interweaving of reflections, framings, and architectural elements constitutes a transition area between interior and exterior worlds, reflecting, in both the literal and figurative sense, how exterior and interior areas are seen blending into one another. The courtyard area enclosed by windows becomes itself an interior space, the impression of a sort of 'caged world,' a GehäuseWelt (Simmel).

Repetitions, series of framing structures, light projections, shadows, and reflections come into view. This blending of framings or openings that do not lead into the open, of reflections and light effects that create projections in the interior through a 
window, and of the iteration of structures is impressively staged in Four Rooms (fig. 4). We look into a suite of four rooms. They are obviously high-ceiling rooms, but they can only be seen in a cut-off view. A door leaf stands out into the room, the outermost edge of the door touches the edge of the painting and divides the space of the picture. Light is reflected on the door and enters from the left through a window, which is not visible but is hinted at by a light curtain. Behind the door, in its slipstream, a small side table can be seen, on which stands an empty bowl with light reflections. Above it on the wall, there is a dark-framed mirror in which a reflection is visible, too, even though it is located in the shadow. It draws the eye into a perspectival depth of space - as if it were reflecting an opposite window, though it seems to mirror the door.

Like a small window in the wall, the mirror creates the impression that it leads outside. It strangely corresponds with what can be seen through the large open door: a suite of rooms. The incidence of light is always accentuated by shading and the prominence of the white lacquered doors. One might also think of mirror cabinets in baroque castles, which work with such optical illusions.

The successive rooms are separated from each other by door frames, thresholds, and differently angled doors. Thick wooden planks draw perspective lines to the last room, but always with slight misalignments, and lead to a dark canapée and a painting on the wall, which is again cut off.

Time and again, it is cut framings that dominate this parkours of iteration and alteration. Already in the room in the foreground, this is pointed to by the opened door. A cut profile on the door leaf draws attention to the back of the door, which, if closed, would fit into a half-height wooden paneling. And the dark-framed mirror also hangs on a framing board. The interlocking of borders and cut framings determines the perception of the suite of rooms. It becomes a cabinet of mirrors or a nesting of rooms.

Hammershøi owned some writings by Kierkegaard. ${ }^{19}$ His paintings, like Kierkegaard's room scenes of poetic criticism, involve the viewer in multiple perspectives, operating with iterations, reflections, refractions of light, and situation variations. Let us recall Kierkegaard's actiones in distans, i.e., a poetic, image-generating process that lets us envision a spectrum of different situations which are being played through. The impression of the realistic representation is captivating, but the painter operates with compositional shifts and reflections. Objects are varied, figures are placed differently, thus modifying the viewer's perspective of view. Poetic reflection and micrological investigations of reality enter into a dialectical relationship. The room as a private retreat and expression of an attitude towards life is shown in differing compartments and framings, i.e., from prismatically varying perspectives.

Repetition, recurring situations, and, again and again, edgings and framings stand out. Time seems to have come to a standstill in these frames, even when the 
suite of rooms is serially extended, allowing the gaze to wander into the depths of the room, or when the incidence of light refers to an external time determined by the changing position of the sun, or when figures in unchanging poses testify to sequences of former movement. Hammershøi's staging of rooms may be interpreted as poetic reflection chambers, as spaces of painterly poetry and criticism. But at best, they give a hint or lay a trace. Is the world dense and, as it appears, timelessly frozen in the face of the raging monotony of industrial capitalist seriality? Does it deny both the past and the future? As unfathomable as the lines of the room is the "doubling of the room, which appears to be mirrored without being mirrored: like these rooms, all the appearances of history may perhaps resemble each other, as long as they themselves, in bondage to nature, persist in appearances" (Adorno 1979, 69; trans. A.E.).

Is this an implicit critique of a collective consciousness that neglects the past, because everything or the ever new that happens passes, as it were, as a constant repetition? Does the experience of time standing still critically testify to an ahistorical perception of the world of modernity and to the perpetual recurrence of the same, which makes of modernity a Kafkaesque hell of eternity, as Benjamin states, so that the perception of space (or of a room) in which this experience of time is expressed constitutes a transparency of penetration, overlaying and covering? (Benjamin 1982, GS V.2, 676 [S 1,5]; 678-679 [S 2,1]) All this may be alluded to here.

Let us return to another episode of Kierkegaard's Repetition, where precisely the impossibility of stealing out of time becomes the object of poetic criticism. And indeed, models of the perception of time here correspond with the representation of a parkours of interiors and suites of rooms.

One climbs the stairs to the first floor in a gas-illuminated building, opens a little door, and stands in the entry. To the left is a glass door leading to a room. Straight ahead is an anteroom. Beyond are two entirely identical rooms, identically furnished, so that one sees the room double in the mirror. The inner room (inderste Værelse) is tastefully illuminated. A candelabra stands on a writing table; a gracefully designed armchair upholstered in a red velvet stands before the desk. The first room is not illuminated. Here the pale light of the moon blends with the strong light from the inner room (indre Værelse). Sitting in a chair by the window, one looks out on the great square, sees the shadows of passersby hurrying along the walls (Forbigaaendes Skygger ile hen over Murene); everything is transformed into a stage setting (scenisk Decoration). A dream world glimmers in the background of the soul. (Kierkegaard 1983, 151-152)

But here, too, the comfort of a retreat concealed in the moonlight is deceptive. The dreamy hope "as if the end of the world had already come" (152), ${ }^{20}$ the attempt to approach the world in a dreamily distanced way like a "scenisk Decoration," and the endeavor to find distraction in (actual) theater performances prove more and more illusory for the protagonist - and in the end, he wishes to shatter to pieces the backdrops of the bourgeois world and the props of the writing room ("I almost

20 This ambiguously alludes to the end of earthly time, that is, in theological terms, the time of fulfillment and redemption, but also the time of final judgment. 
smashed it to pieces"). "Half-awake, half-dreaming," the red velvet chair becomes a foreign object in a home that has become uncanny and the chair is thrown forcefully into a corner. "My home had become dismal to me simply because it was a repetition of the wrong kind." The repetition of a romanticized remembrance proves to be just as impossible as the escape into an open future. "There is no repetition at all." (Kierkegaard 1983, 169)

It is again poetic telegraphs that Kierkegaard makes literarily effective. For instance, when in Sickness unto Death he tells us the story of a murderer, who tries to escape the scene of his crime by train (a sequence of chambers on rails, one might say), but as circumstances dictate, a telegraph is active in one of the cabins and reports that the criminal is on board. Thus, when the wanted man arrives at the next station, he brings the news of his conviction himself. ${ }^{21}$ Adorno has referred to this episode as a parable of civilization in the sense of a reality of the court, which dissolves, and at the same time fulfills, deceptive appearances (Adorno 1979, 67-68).

There is no escape from one's personal life. The individual past, as a crystallization point of a collective history, accompanies us every single moment, even when we take a train in order to escape. This is not fatalism, and it does not interest us here in the theological sense of a higher justice or judgment. What it represents, however, is the problematization of a deceptive sense of security. The attempt to escape from the world and from one's own personal and collective history by seeking to settle down in the caves of private comfort fails, because this very historical world is present everywhere and always surrounding us. As Adorno has often stated with regard to cinematic fiction: The scene is speeding towards us like an express train. ${ }^{22}$

As a topos of consciousness or self-awareness - Nietzsche's chamber of consciousness that we never enter but are only able to see through a small gap - a scenic world is revealed in these inward chambers. In them, however, modes of subjection to an overpowering outer world are perpetuated. And this becomes even more insistent in the twentieth century.

All these poetic chambers operate with a language of furnishing (Einrichtung), which is interwoven with the experience of the social world. Yet, this visual language entails a poetic enigmaticalness, i.e., a poetic criticism that is articulated in paradoxical figures. We do not escape the noise of a threatening outside world by entrenching ourselves. On the contrary, it becomes even louder. Let us listen to a passage from Kafka, whose intense, ambiguous involvement with Kierkegaard has been widely discussed.

Everyone carries a room about inside him. The fact can even be proved by means of the sense of hearing. If someone walks fast and one pricks up one's ears and listens, say in the night, when

21 See Müller 1995, 67-75.

22 As Adorno emphasizes with regard to Kafka, aesthetic distance has become impossible - something which is prototypical for modernism. The contemplative comfort of the reader is shattered, because the catastrophic world does not allow for an uninvolved spectator (see Adorno 2009 [NS], IV, 418). 
everything round about is quiet, one hears, for instance, the rattling of a mirror not quite firmly fastened to the wall. (Kafka 1991, 1)

A night scene - and we do not know where this supposed encounter between the one hurrying through the night and the one hearing the sounds of a wall mirror in the silence takes place. The poetic staging alludes to an inner self-reflection, a clattering self-reflection which has turned into a discordant state and which is betraying its instability through movement; at the same time, it also alludes to a bourgeois interior with wall mirrors, furniture, and social conventions. Listening to the silence within oneself, to the echo space of the inner telegraphs, may remind us of Kierkegaard's sounding shadows. The world seems locked-out, and yet it echoes in the imaginative space of poetic writing, virtually crowding into consciousness and undermining any possible calm.

The poetic chamber is by no means objectless. In its indifference to world events, it suspends any direct relation to the sphere of empirical activities. It negates purposes of self-preservation belonging to lived routines and thus indirectly reflects upon the (im)possibility of another practice. But this happens in aesthetic idioms of distortion, interruption, deformation. Poetic procedures make us susceptible to being at the mercy of the living world at an aesthetic distance. But this distance requires mobility, paradoxical actions, i.e., actiones in distans as a restless back and forth between inside and outside.

The poetic chamber becomes a stage on which the world in its absurd constitution begins to resound. In his reflections on the musical-erotic, Kierkegaard has described the deep layers of the soul's movement as an underlying urge, be it painful or rapturous. This urge ties itself to any everyday experience, is an indicator of the ego's experience of the world, and it requires silence to listen to this interweaving of experience and memory. Can silence, in particular, not bring along an immense volume? Does not the roar of the world sometimes reveal itself through enervating signals or a deafening silence? Will it be the noise of an inner telegraphy, disturbed from the slumber of ignorance? Let us listen to Kafka again:

It is not necessary for you to leave the house. Stay at your table and listen. Don't even listen, just wait. Don't even wait, be completely quiet and alone. The world will offer itself to you to be unmasked, it can't do otherwise, in raptures it will writhe before you. (Kafka 2012, 200; NSF II 140) ${ }^{23}$

Separated from the individual's restless activity, the historical context and the external social world push themselves even more intensely into the enclave of the ego, infiltrating its inner voices and becoming a crystallization point of critical reflection. As we have already seen and heard: poetic rooms do not offer vantage points for comfortable contemplations. They do not allow us to lean back in pleasurable, uninvolved self-reflection, as in a red velvet armchair. Instead, they draw the reader into a

23 See also Kleinwort 2004, 224-225. 
maelstrom and do not leave the sympathizer of secrecy alone, but expose him to indissolubility.

Where reality has taken on the character of hostility, rejection, and inhumanity, or the appearance of an irrational totality, a retreat into inwardness is precisely that which cannot guarantee liberation. Rather, it becomes a prison. The chamber scenes discussed earlier make this unmistakably clear with all their features of abandonment, loneliness, rebellion, and the destructive parody of everyday worlds. They also mirror modes of domestication, a subjection of the self to the norms and habits of bourgeois life: indoor situations thus mirror the outdoor world. This also happens in ambivalent stagings. The following scene will perhaps (at first) evoke the impression of happy fantasy journeys under the father's care. ${ }^{24}$

When at times Johannes asked permission to go out, his request was usually refused; but occasionally his father, by way of compensation, offered to take his hand and go for a walk up and down the floor [...]. They walked through the city gate to the country palace nearby or to the seashore or about the streets - according to Johannes's wish, for his father was capable of everything. While they walked up and down the floor, his father would tell about everything they saw. They greeted the passers-by; the carriages rumbled past, drowning out his father's voice; the pastry woman's fruits were more tempting than ever. [...] If the path was unfamiliar to Johannes, he made associations, while his father's omnipotent imagination was able to fashion everything, to use every childish wish as an ingredient in the drama that was taking place. (Kierkegaard 1985, 120)

This scene has often been read biographically. But the promenade through the room, which transposes structures of the outside world into the illusory world of the inside, can not only be read as a protected flânerie at the father's hand. Kierkegaard's interiors are neither comfortable nor always inviting. It is the aesthetic form - the antagonism of moments, repetitions, and paradoxical situations - that strives against illusionary arrangements and allows for both the experience of life's destructive forces and an awareness of the deceptive illusion of comfortable inwardness. The poetical chamber, i.e., the furniture of aesthetic language, makes these distortions tangible.

You must push your head through the wall. It is not difficult to push it through because it is made of thin paper. But what is difficult is not to let yourself be deceived by the fact that there is already an extremely deceptive painting on the wall showing you pushing through the wall. It tempts you to say: Don’t I push it through all the time? (Kafka 1954, 303)

We take up here only some flashlights from Kafka leading us to a poetic chamber of the late twentieth century. We are now in a video installation by the artist Gary Hill. The audience has to enter a darkened room, a black cube, within which it is confronted with a video projection on one of the walls, a projection that repeatedly pops up

24 Implicitly, we can again think here of the entanglement of the imaginative roles of child and aged man. This might prompt us to think about standardized images of reality that are, literally, cut out here. 
and then disappears again, cut-off, exhibiting only shattered sequences: a cinematographic shadow play. With the flashing light constantly flickering, we can see for a moment a male figure that seems to throw itself against a wall, as if seeking to break through it. At the same time the projected figure on the wall seems to jump against this imaginary borderline time and again, we can listen to the chanting of a poetic text that is just as shattered, as breathlessly flashing as the light reflections a never-ending loop.

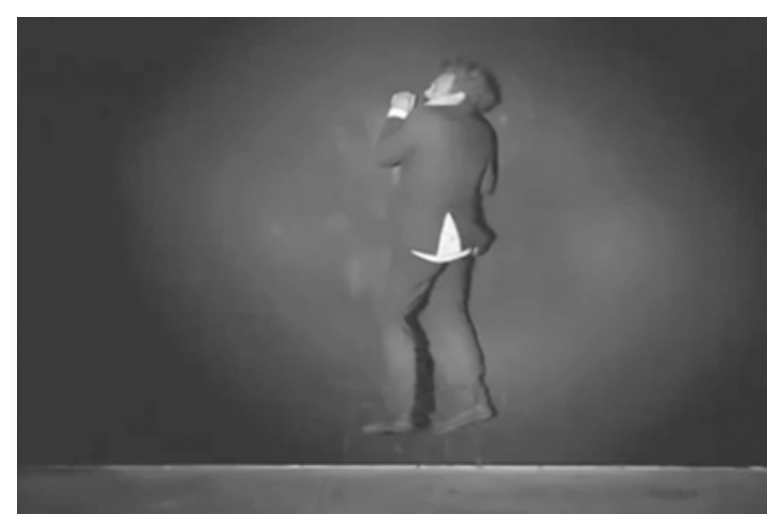

Fig. 6: Gary Hill. Wall Piece, 2000. Single-channel video/sound installation

\begin{abstract}
A word is worth .001 pictures. To be transfixed is no longer an option. I am in a way blind. I live time through a succession of pictures I've known since when. But it's precisely this when that haunts - it eats out the looking cavities and smiles inward like a Cheshire cat. What I might name as "the immediate surroundings" has all but vanished. I have no place. No feet. I've lost the vague idea of limbs. Legs feel more like logs arranged for a fire. I remember a dream of holding the other's heart in my hand; for a moment I live the pulse of another being. [...] This is not me. I'm not accountable. It wasn't thought out. It has no relation to thought. This is that hole that everything must pass through. [...] It burrows itself in, blows up and begins again plural--Points. Cells. ${ }^{25}$
\end{abstract}

An inversion of the borderlines between inside and outside. Cabin, cell, prison - or blasting cap of language? The paradoxical inside-out and the endless attempt to escape one's shattered self-perception may be seen as a radical staging of poetic criticism. We leave the last words to Kafka:

Der Kampf mit der Zellenwand

Unentschieden

(Kafka, NSF II, 383) ${ }^{26}$

$25 \mathrm{http} / / /$ garyhill.com/work/mixed_media_installation/wall-piece.html 26 "The war with the cell wall" - "Undecided" (qtd. in Corngold 2011, 14). 


\section{Bibliography}

Adorno, Theodor W. Ästhetische Theorie. Gesammelte Schriften. Vol. VII. Ed. Rolf Tiedemann, assisted by Gretel Adorno, Susan Buck-Morss, and Klaus Schultz. Frankfurt/M.: Suhrkamp, 1970.

Adorno, Theodor W. Kierkegaard. Konstruktion des Ästhetischen. Gesammelte Schriften. Vol. II. Ed. Rolf Tiedemann. Frankfurt/M.: Suhrkamp, 1979.

Adorno, Theodor W. Nachgelassene Schriften (NS). Section IV, Vol. 3. Ästhetik (1958/59). Ed. Eberhard Ortland. Frankfurt/M.: Suhrkamp, 2009.

Alsdorf, Bridget. “Hammershoi’s Either/Or.” Critical Inquiry 42.2 (Winter 2016): 268-305.

Barthes, Roland. La chambre claire. Note sur la photographie. Paris: Gallimard, 1980.

Barthes, Roland. Camera lucida. Reflections on photography. Trans. Richard Howard. New York: Hill and Wang, 2006.

Becker, Claudia. Zimmer-Kopf-Welten. Motivgeschichte des Intérieurs im 19. Und 20. Jahrhundert. Munich: Fink, 1990.

Benjamin, Walter. Kleine Prosa. Baudelaire-Übertragungen. Gesammelte Schriften (GS). Vol. IV. Ed. Tillmann Rexroth. Frankfurt/M.: Suhrkamp, 1972.

Benjamin, Walter. Das Passagen-Werk. GS. Vol. V. Ed. Rolf Tiedemann. Frankfurt/M.: Suhrkamp, 1982.

Blumenberg, Hans. Theorie der Unbegrifflichkeit. Frankfurt/M.: Suhrkamp 2007.

Brüggemann, Heinz. Walter Benjamin. Über Spiel, Farbe und Phantasie, Würzburg: Königshausen \& Neumann, 2007.

Chaouli, Michel. Das Laboratorium der Poesie. Chemie und Poetik bei Friedrich Schlegel. Munich et al.: Schöningh, 2004.

Corngold, Stanley. "Special views on Kafka's cages." Freedom and Confinement in Modernity. Kafka's Cages. Eds. Kordela A. Kiarina and Dimitris Vardoulakis. New York: Palgrave Macmillian 2011. 9-28.

Glöckner, Dorothea. Kierkegaards Begriff der Wiederholung. Eine Studie zu seinem Freiheitsverständnis. Berlin and New York: De Gruyter, 1998.

Haug, Steffen. Benjamins Bilder: Grafik, Malerei und Fotografie in der ,Passagenarbeit‘. Paderborn: Fink, 2017.

Hemkendreis, Anne. Die monochromen Interieurbilder Vilhelm Hammershøis. Paderborn: Fink, 2016.

Kafka, Franz. Dearest Father. Stories and Other Writings. Eds. Ernest Kaiser and Eithne Wilkins. New York: Schocken, 1954.

Kafka, Franz. Nachgelassene Schriften und Fragmente in der Fassung der Handschriften. Vol. II (NSF II). Ed. Jost Schillemeit. Frankfurt/M.: Fischer, 1992.

Kafka, Franz. The Blue Octavo Notebooks. Cambridge, MA: Exact Change, 1991.

Kafka, Franz. A Hunger Artist and Other Stories. Trans. Joyce Crick. Oxford: Oxford University Press 2012.

Kierkegaard, Søren. Enten - Eller. Kopenhagen: Gyldenrdalske, 1920.

Kierkegaard, Søren. Kierkegaard's Writings. Eds. Edna H. Hong and Howard V. Hong. Vol. III/1: Either/Or (1988); Vol. VI: Fear and Trembling/Repetition (1983); Vol. VII: Philosophical Fragments (1985); Vol. XIX: Sickness Unto Death. A Christian Psychological Exposition for Upbuilding and Awakening (2013). Princeton, NJ: PUP, 1983-2013.

Kierkegaard, Søren. The Journals of Soren Kierkegaard [JP]. Ed and trans. Alexander Dru. New York: Oxford University Press, 1938.

Kleinwort, Malte. Kafkas Verfahren: Literatur, Individuum und Gesellschaft im Umkreis von Kafkas Briefen an Milena. Würzburg: Königshausen \& Neumann, 2004. 
Leske, Marie. Illustriertes Spielbuch für Mädchen. Unterhaltende und anregende Belustigungen, Spiel und Beschäftigungen für Körper und Geist, im Zimmer sowie im Freien. Berlin and Heidelberg: Springer, 1914.

Liessmann, Konrad Paul. "Schattenrisse. Das Tagebuch des Verführers: Im Schatten des Eros." Sören Kierkegaard: Entweder - Oder (Klassiker Auslegen 67). Eds. Hermann Deuser and Markus Kleinert. Berlin: De Gruyter, 2017. 131-150.

Müller, Ernst. “'Der Einsame, der die Fahrt eines Eisenbahnzuges gestört hat.' Wahrnehmungs-, Kommunikations- und Bewegungstechniken bei Kierkegaard." Wahrnehmung und Geschichte. Markierungen zur Aisthesis materialis. Eds. Bernhard J. Dotzler and Ernst Müller. Berlin: De Gruyter, 1995. 43-82.

Schlegel, Friedrich. "Kritische Fragmente" [1797]. Kritische Friedrich-Schlegel Ausgabe (KFSA). Vol. II. Ed. Hans Eichner. Paderborn et al.: Schöningh, 1967. 147-163.

Schlegel, Friedrich. "Athenäums-Fragmente” [1798a]. KFSA. Vol. II. Ed. Hans Eichner. Paderborn et al.: Schöningh, 1967. 165-255.

Schlegel, Friedrich. “Über Goethes Meister” [1798b]. KFSA. Vol. II. Ed. Hans Eichner. Paderborn et al.: Schöningh, 1967. 126-146.

Schlegel, Friedrich. "Gespräch über die Poesie" [1800]. KFSA. Vol. II. Ed. Hans Eichner. Paderborn et al.: Schöningh, 1967. 284-362.

Schreiber, Gerhard. Apriorische Gewissheit. Das Glaubensverständnis des jungen Kierkegaard und seine philosophisch-theologischen Voraussetzungen (Kierkegaard Studies 30). Berlin: De Gruyter, 2014.

Schürmann, Uta. Komfortable Wüsten. Das Interieur in der Literatur des europäischen Realismus des 19. Jahrhunderts (Literatur - Kultur - Geschlecht. Studien zur Literatur- und Kulturgeschichte 65). Vienna: Böhlau, 2015.

Stiegler, Bernd. Reisender Stillstand. Eine kleine Geschichte des Reisens im und um das Zimmer herum. Frankfurt/M.: Fischer, 2010.

Tajafuerce, Begonya Saez. "Kierkegaardian seduction, or the aesthetic actio(nes) in distans." Diacritics 30.1 (Spring 2000): $78-88$.

\section{List of figures}

Fig. 1: Etienne de Jouy. L'Hermite de la Chaussée-d'Antin, ou Observations sur les mœurs et les usages parisiens au commencement du XIXe siècle. Tome ler (4ème édition) \& Tome Illème (5ème édition), revue, corrigée et ornée de deux gravures. Paris: Pillet, Imprimeur-Libraire, 1814. (Photograph A.E.)

Fig. 2: Marie Leske. Illustriertes Spielbuch für Mädchen. Unterhaltende und anregende Belustigungen, Spiel und Beschäftigungen für Körper und Geist, im Zimmer sowie im Freien. Berlin and Heidelberg: Springer-Verlag, 1914. 99. (Photograph of detail: A.E.)

Fig. 3: Marie Leske. Illustriertes Spielbuch für Mädchen. Unterhaltende und anregende Belustigungen, Spiel und Beschäftigungen für Körper und Geist, im Zimmer sowie im Freien. Berlin and Heidelberg: Springer-Verlag, 1914. 102. (Photograph of detail: A.E.)

Fig. 4: Vilhelm Hammershøi. Interior. "The Four Rooms." 1914 (Oil on canvas, 33 1/2 × 27 4/5 inch; $85 \times 70.5 \mathrm{~cm})$. Ordrupgaard, Kopenhagen. Hammershøi und Europa. Ed. Sven Bjerkhof. Statens Museum for Kunst, Kopenhagen; Kunsthalle der Hypo-Kulturstiftung. Munich, London, and New York: Prestel Verlag, 2012. 107 [panel 83]. (c) Statens Museum for Kunst, Kopenhagen.

Fig. 5: Vilhelm Hammershøi, Courtyard. Strandgade 30. 1899 (Oil on canvas, 65,7 × 47,0.3 cm). Toledo Museum of Art, Ohio. L'Univers poétique de Vilhelm Hammershøi. 1864-1916. Eds. 
Anne-Brigitte Fonsmark, Mickael Wivel, and Henri Loyrette. Paris: Réunion des musées nationaux, 1997. 73. (c) Ordrupgaard, 1997; Réunion des musées nationaux, 1997.

Fig. 6: Gary Hill. Wall Piece, 2000. Single-channel video/sound installation. (Film-Still. Photograph: A.E.) 